\title{
Use of Semiochemical Products in Monitoring and Control of Epicometis Hirta Poda
}

\author{
Ion OLTEAN ${ }^{1}$, Laura Ioana MACAVEI ${ }^{1}$, Iuliana VASIAN ${ }^{2}$, Stefania TÖTÖS ${ }^{2}$, Mircea VARGA ${ }^{1}$, Teodora \\ FLORIAN $^{1 *}$ \\ ${ }^{1}$ Faculty of Agriculture, Department Environment and Plant Protection, University of Agricultural \\ Sciences and Veterinary Medicine Cluj-Napoca, Calea Mănăştur 3-5, 400372, Cluj-Napoca, Romania \\ ${ }^{2}$ Institute for Research in Chemistry "Raluca Ripan”, Babes-Bolyai” University, Cluj-Napoca, 30 \\ Fantanele str., 400294, Cluj-Napoca, Romania \\ *Corresponding author: florian.teodora@yahoo.com
}

Bulletin USAMV series Agriculture 72(2)/2015

Print ISSN 1843-5246; Electronic ISSN 1843-5386

DOI 10.15835/buasvmcn-agr: 11705

\begin{abstract}
Epicometis hirta Poda. is a dangerous pest which can be observed on annual crops and also on fruit tree species.

The adult is a beetle can be easily recognized due to existing pubescence found all over it's body. The pest causes damage by consuming the reproductive organs of flowers. Adults are phytophagous and feed on leaves and flowers of plants such as orchard trees, cereals or ornamental plans. The timeing chemical control against this species is very difficult considering that the moment of sprays application is during bloom,thus the pollinating entomofauna is affected. Therefore the need to develop alternative control methods is highlighted. Semiochemical products represent a method of perspective whereas involve only the target species. For this purpose the team of entomology discipline along with Institute of Chemistry "Raluca Ripan"colegues, tested the attractiveness of two new synthetic products which were placed in three types of traps (Type 1, Type 2, Type 3). Experiments were located in UASVM Cluj Napoca Orchard, fruit tree farm Steluța and fruit tree farm Agroindustriala Cluj Napoca. The best results were obtained by Type 1 trap, in all three locations.
\end{abstract}

Keywords: bumblebees, blue trap, monitoring strategies.

\section{INTRODUCTION}

Epicometis hirta is a polyphagus pest, being reported on 48 species of plants (Subchev et al., 2011). The damage is produced by adults which consume the reproductive organs of host flowers, such as orchard trees, cereals or ornamental plans (Aydin, 2011; Vuts et al., 2009). It's attack can diminish up to $70 \%$ of flowers in nurseries and young cherry orchards (Kutinkova and Andreev, 2004; Roşca et al., 2011).

In spring, starting from April, the adults become active and fly to flowers of springblossoming fruit trees or to different weeds, where they feed until July, with a maximum peack of flight in June (Roşca et al., 2011; Subchev et al., 2011)
The control of this pest can be done only by a rational application of a complex control strategy. Therefore several methods as fizical, mecanical, biological, biotehnical or chemical are used. The chemical control of this species is very difficult considering that the moment of spray application must be done during bloom, therefore the pollinating entomofauna is affected. The mechanical control methods consist in direct colectig of larvae and adults. In order to apply a successful control strategy, morphological, biological ond behavioral particularities of this species must be known.

Whereas the pest presents positive phototropism for certain wave length, stiky panells can be used for it's control, however this 
method is adequate only for limited areas. In the process of locating the host plant, the insect uses both chemical (chemical mediators) and vizual cues (Vuts et al., 2009).

The aim of this experiment was to evaluate the efficacy of two semiochemical products (produced by Institute of Chemistry "Raluca Ripan") in three type of traps, in order to be used for monitoring actions of Epicometis hirta species.

\section{MATERIALS AND METHODS}

The experiment took place in the year 2015, during the adults flight.

Traps were placed in three different locations from Cluj-Napoca area: Steluța farm (cherry orchard), Agroindustriala farm (cherry orchard) and USAMV Cluj-Napoca (apaple orchard).
We used two types of semiochemical blends wich were placed in three diffrent designs of traps. Type 1 - blue trap with funnel; Type 2 - white trap placed on soil level, Type 3 - white trap placed on tree crown (Fig. 1.).

The setup of experiment took plase on different dates: 21.04. 2015 for cherry orchards, respectively in 17.04.2015 in apple orchard of USAMV Cluj-Napoca.

\section{RESULTS AND DISCUSSION}

The results regarding number of catches for each experimental treatment form each location, are presented in (Tab. 1.), (Tab. 2.) and (Tab. 3.).

A syntesis regarding the functionality of the two types of semiochemical lures in capturing

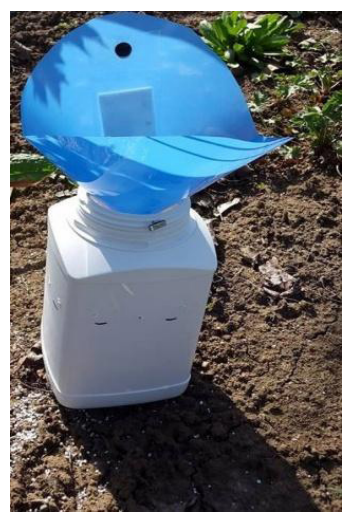

Type 1

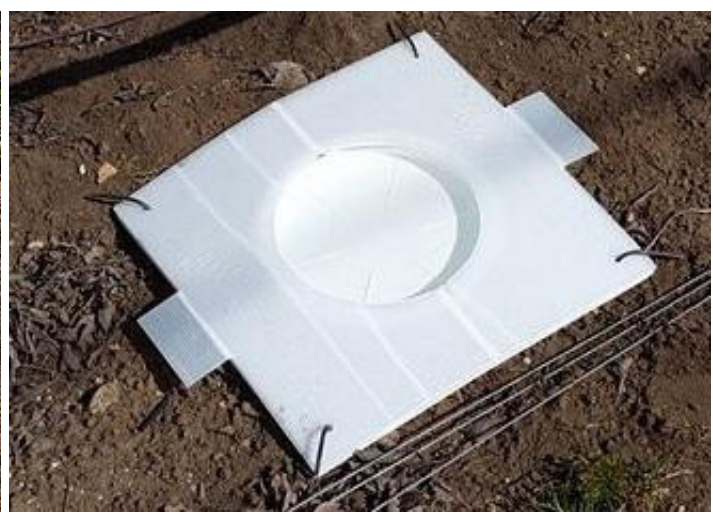

Type 2

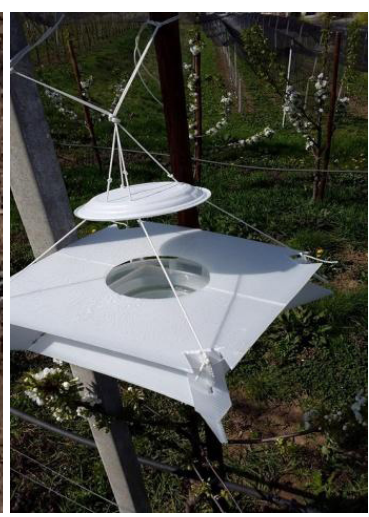

Type 3

Fig. 1.

Tab. 1. Monitoring of Epicometis hirta species in cherry orchard (Steluța farm)

\begin{tabular}{|c|c|c|c|c|c|}
\hline Location & Fruit tree & Trap type & $\begin{array}{c}\text { Observation } \\
\text { date }\end{array}$ & $\begin{array}{c}\text { Number of } \\
\text { Epicometis } H \text {. adults }\end{array}$ & $\begin{array}{r}\text { Other insects } \\
\text { (bumble bees) }\end{array}$ \\
\hline \multirow{6}{*}{$\begin{array}{l}\text { Steluța } \\
\text { Farm }\end{array}$} & \multirow{6}{*}{ Cherry } & Blue trap 1 & \multirow{6}{*}{04.05 .2015} & 4 & - \\
\hline & & Blue trap 2 & & 18 & - \\
\hline & & Blue trap 3 & & - & 13 \\
\hline & & Blue trap 4 & & 13 & 22 \\
\hline & & White trap (crown level) & & & \\
\hline & & White trap (soil level) & & & \\
\hline \multirow{6}{*}{$\begin{array}{l}\text { Steluța } \\
\text { Farm }\end{array}$} & \multirow{6}{*}{ Cherry } & Blue trap 1 & \multirow{6}{*}{18.05 .2015} & 10 & 7 \\
\hline & & Blue trap 2 & & 40 & - \\
\hline & & Blue trap 3 & & 5 & 3 \\
\hline & & Blue trap 4 & & 45 & 11 \\
\hline & & White trap (crown level) & & 1 & - \\
\hline & & White trap (soil level) & & - & - \\
\hline
\end{tabular}


Epicometis hirta adults and other species, is represented in (Tab. 4.) and (Tab. 5.).

From (Tab. 4.) it can be noticed the total number of pest's adults colected during experimental period, number that ranged from 135 individuals (Agroindustriala farm) to 41 individuals (Steluța farm), therefore the power of atraction to semiochemical lure 1 is proven. Similar results were obtained by Schemra et al.,(2004) şi TÓTH et al.,(2004). However, this blend has a negative collateral effect to ecosystem through the high number of bumble bees (516 individuals) that have been captured; the total catches/location ranged from 48 individuals in

Tab. 2. Monitoring of Epicometis hirta species in cherry orchard (Agroindustriala farm)

\begin{tabular}{|c|c|c|c|c|c|}
\hline Location & Fruit tree & Trap type & $\begin{array}{c}\text { Observation } \\
\text { date }\end{array}$ & $\begin{array}{c}\text { Number of } \\
\text { Epicometis H. adults }\end{array}$ & $\begin{array}{c}\text { Other insects } \\
\text { (bumble bees) }\end{array}$ \\
\hline \multirow{6}{*}{$\begin{array}{c}\text { Agroindustriala } \\
\text { Farm }\end{array}$} & \multirow{6}{*}{ Cherry } & Blue trap 1 & \multirow{6}{*}{04.05 .2015} & 4 & 50 \\
\hline & & Blue trap 2 & & 18 & 52 \\
\hline & & Blue trap 3 & & - & 109 \\
\hline & & Blue trap 4 & & 13 & 104 \\
\hline & & White trap (crown level) & & & - \\
\hline & & White trap (soil level) & & & - \\
\hline \multirow{6}{*}{$\begin{array}{l}\text { Agroindustriala } \\
\text { Farm }\end{array}$} & \multirow{6}{*}{ Cherry } & Blue trap 1 & \multirow{6}{*}{$-18.05 .2015$} & 2 & 15 \\
\hline & & Blue trap 2 & & - & 5 \\
\hline & & Blue trap 3 & & - & 4 \\
\hline & & Blue trap 4 & & 4 & 10 \\
\hline & & White trap (crown level) & & - & - \\
\hline & & White trap (soil level) & & - & - \\
\hline
\end{tabular}

Tab. 3. Monitoring of Epicometis hirta species in apple orchard (USAMV Cluj-Napoca)

\begin{tabular}{|c|c|c|c|c|c|}
\hline Location & Fruit tree & Trap type & $\begin{array}{c}\text { Observation } \\
\text { date }\end{array}$ & $\begin{array}{c}\text { Number of } \\
\text { Epicometis H. adults }\end{array}$ & $\begin{array}{l}\text { Other insects } \\
\text { (bumble bees) }\end{array}$ \\
\hline \multirow{6}{*}{$\begin{array}{l}\text { Orchard } \\
\text { USAMV } \\
\text { Cluj-Napoca }\end{array}$} & \multirow{6}{*}{ Apple } & Blue trap 1 & \multirow{6}{*}{24.04 .2015} & 4 & 2 \\
\hline & & Blue trap 2 & & 7 & - \\
\hline & & Blue trap 3 & & 2 & - \\
\hline & & Blue trap 4 & & 5 & 3 \\
\hline & & White trap (crown level) & & - & - \\
\hline & & White trap (soil level) & & - & - \\
\hline \multirow{6}{*}{$\begin{array}{l}\text { Orchard } \\
\text { USAMV } \\
\text { Cluj-Napoca }\end{array}$} & \multirow{6}{*}{ Apple } & Blue trap 1 & \multirow{6}{*}{1.05 .2015} & 8 & 10 \\
\hline & & Blue trap 2 & & 4 & 4 \\
\hline & & Blue trap 3 & & 15 & 4 \\
\hline & & Blue trap 4 & & 4 & 7 \\
\hline & & White trap (crown level) & & 1 & - \\
\hline & & White trap (soil level) & & - & - \\
\hline \multirow{6}{*}{$\begin{array}{l}\text { Orchard } \\
\text { USAMV Cluj- } \\
\text { Napoca }\end{array}$} & \multirow{6}{*}{ Apple } & Blue trap 1 & \multirow{6}{*}{8.05 .2015} & 4 & 3 \\
\hline & & Blue trap 2 & & 5 & 4 \\
\hline & & Blue trap 3 & & - & 4 \\
\hline & & Blue trap 4 & & 1 & 7 \\
\hline & & White trap (crown level) & & - & - \\
\hline & & White trap (soil level) & & & \\
\hline
\end{tabular}


Tab. 4. Total number of catches registered by blue trap (semiochemical blend 1)

\begin{tabular}{ccc}
\hline Location & $\begin{array}{c}\text { No. of } \\
\text { catches }\end{array}$ & $\begin{array}{c}\text { Other } \\
\text { species }\end{array}$ \\
\hline Steluța farm & 135 & 56 \\
\hline Agroindustriala farm & 41 & 349 \\
\hline USAMV Cluj-Napoca orchard & 60 & 48 \\
\hline Total & 236 & 453 \\
\hline
\end{tabular}

Tab. 5. Total number of catches registered by semiochemical blend 2 in the tested trap designs

\begin{tabular}{ccccc}
\hline \multirow{2}{*}{ Location } & \multicolumn{2}{c}{ No. of captures } & \multicolumn{2}{c}{ Other species } \\
\cline { 2 - 5 } & $\begin{array}{c}\text { Soil level } \\
\text { trap }\end{array}$ & $\begin{array}{c}\text { Crown } \\
\text { level trap }\end{array}$ & $\begin{array}{c}\text { Soil level } \\
\text { trap }\end{array}$ & $\begin{array}{c}\text { Crown } \\
\text { level trap }\end{array}$ \\
\hline Steluța farm & - & & - & - \\
\hline $\begin{array}{c}\text { Agroindustriala } \\
\text { farm }\end{array}$ & - & - & - & - \\
\hline $\begin{array}{c}\text { USAMV } \\
\text { Cluj-Napoca } \\
\text { orchard }\end{array}$ & - & 1 & - & - \\
\hline Total & - & 1 & - & \\
\hline
\end{tabular}

USAMV Cluj-Napoca orchard to 349 bumble bees in Agroindustriala farm.

In order to improve the functionality of this type of product, future reasearch is needed.

On the other hand, studies regarding the color induced selectivity are needed. It is possible that a big part of the bumble bees captured, were also atracted by the color of trap .

The semiochemical lure 2 did not show satisfactory attraction to Epicometis hirta or other species (Tab. 5.), therefore it will not be considered for our further studyes.

\section{CONCLUSION}

1. Semiochemical lure 1 presents high attractiveness for adults of Epicometis hirta species.

2. In order to be used in monitoring actions, future research concencing the selectivity of semiochemical lure 1 are needed.

Acknowledgments. This paper was published under the frame of European Social Fund, Human Resources Development Operational Programme 2007-2013, project no. POSDRU/159/1.5/S/ 132765 .

\section{REFERENCES}

1. Aydin G (2011). Plant Phenology-Related Shifts in Color Preferences of Epicometis (Tropinota) Hirta (Coleoptera: Scarabaeidae: Cetoniinae) Adults - Key to Effective Population Monitoring and Suppression. Fla Entomol 94: 832-838.

2. Kutinkova H, Andreev $\mathrm{R}$ (2004). Integrated pest management in sweet cherry (Prunus avium L.) orchards in Bulgaria. J Fruit Ornam Plant Res 12(Spec ed): 41-47.

3. Roșca I, Oltean I, Mitrea I, Tălmaciu M, Petanec DI, Bunescu HȘ, Istrat ER, Horia Ș, Tălmaciu N, Stan C, Micu LC (2011). Tratat de entomologie generală şi specială. Alpha MDN Buz?u.

4. Schmera D,Tóth M, Subchev M, Sredkov I, Szarukán I, Jermy T, Szentesi Á (2004). Importance of visual and chemical cues in the development of an attractant trap for Epicometis (Tropinota) hirta Poda (Coleoptera: Scarabaeidae). Crop Protection 23 (10): 939-944.

5. Subchev MA, Toshova TB, Andreev RA, Petrova VD, Maneva VD, Spasova TS, Marinova NT, Minkov PM, Velchev DI (2011). Employing floral baited traps for detection and seasonal monitoring of Tropinota (Epicometis) hirta (Poda)(Coleoptera: Cetoniidae) in Bulgaria. Acta Zool Bulg 63: 269-276.

6. Tóth M, Schmera D, Imrei Z (2004). Optimization of a Chemical Attractant for Epicometis (Tropinota) hirta Poda. Z Für Naturforschung C 59: 288-292.

7. Vuts J, Szarukán I, Subchev M, Toshova T, Tóth M (2009). Improving the floral attractant to lure Epicometis hirta Poda (Coleoptera: Scarabaeidae, Cetoniinae). J Pest Sci 83: 15-20. 